\title{
PEMBERDAYAAN KELUARGA DENGAN TINGKAT KECEMASAN PASIEN RAWAT INAP DI RSUD DR MOEWARDI
}

\author{
${ }^{1}$ Nuriyah Yuliana, ${ }^{2}$ Triana Mirasari \\ ${ }^{1}$ Sarjana Keperawatan, STIKes Mitra Husada Karanganyar, Email: nuriyah yuliana@yahoo.com \\ ${ }^{21}$ Sarjana Keperawatan, STIKes Mitra Husada Karanganyar, Email: trianamirasari@yahoo.com
}

\begin{abstract}
ABSTRAK
Latar belakang: Dukungan keluarga baik secara langsung maupun tidak langsung dapat mengurangi rasa cemas pada seseorang yang dirawat dirumah sakit. Dukungan keluarga secara emosional merasa nyaman karena diperhatikan, disayang, dihargai, menjadi percaya diri, serta mampu melihat dan menumbuhkan harapan masa depan sehingga mampu menangkal dan mengurangi kecemasan. Tujuan: Mengetahui pemberdayaan keluarga dengan tingkat kecemasan pasien rawat inap RSUD Dr. Moewardi. Metode: Penelitian ini menggunakan metode penelitian analitik dengan pendekatan cross sectional. Pengambilan sampel menggunakan teknik purposive sampling, dengan jumlah sampel penelitian 57 orang responden yang memenuhi kriteria untuk dijadikan populasi dalam penelitian ini, sedangkan instrument penelitian menggunakan kuesioner. Analisa bivariat menggunakan analisis korelasi Kendall's

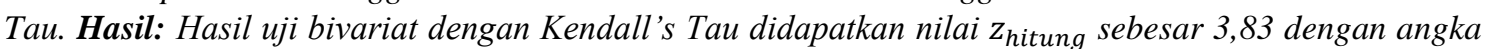
signifikansi $\rho_{\text {value }}=0,000$, dari hasil tersebut diketahui $Z_{\text {hitung }}(3,83)>Z_{\text {tabel }}(1,96)$ dan angka signifikansi $\alpha<005$ sehingga Ho ditolak dan Ha diterima, maka ada hubungan yang signifikan antara antara pemberdayaan keluarga dengan tingkat kecemasan pada pasien rawat inap di RSUD Dr. Moewardi. Kesimpulan: Ada hubungan antara pemberdayaan keluarga dengan tingkat kecemasan pada pasien rawat inap di RSUD Dr. Moewardi.
\end{abstract}

Kata Kunci: Pemberdayaan Keluarga, Tingkat Kecemasan, Preoperasi.

\begin{abstract}
Background: Family support, both directly and indirectly can reduce anxiety in someone who is treated in hospital. Emotional family support feels comfortable because they are cared for, loved, valued, become confident, and are able to see and grow hopes for the future so they are able to ward off and reduce anxiety. Objective: To find out the empowerment of families with the anxiety level of inpatients at RSUD Dr. Moewardi. Method: This study uses analytical research methods with cross sectional approach. Sampling using a purposive sampling technique, with a number of research samples of 57 respondents who met the criteria for population in this study, while the research instrument used a questionnaire. Bivariate analysis uses Kendall's Tau correlation analysis. Results: Bivariate test results with Kendall's Tau obtained $z$ count value of 3.83 with a significance number $\rho$ _value $=0,000$, from the results known $z_{-}$count (3.83)> Z_table (1.96) and significance value $\alpha<005$ so that Ho was rejected and Ha accepted, then there is a significant relationship between family empowerment with anxiety levels in hospitalized patients at RSUD Dr. Moewardi. Conclusion: There is a relationship between family empowerment and the level of anxiety in hospitalized patients at RSUD Dr. Moewardi.
\end{abstract}

Keywords: Family Empowerment, Anxiety Level, Preoperative

\section{PENDAHULUAN}

Tindakan pembedahan merupakan ancaman potensial maupun actual pada integritas seseorang yang dapat membangkitkan reaksi stress psikologis maupun fisiologis. Fase pre operatif dimulai ketika keputusan untuk intervensi bedah dibuat dan berakhir ketika pasien dikirim ke meja operatif (Asmadi, 2008). Kecemasan merupakan salah satu reaksi emosional yang sering timbul sebelum pasien dilakukan operasi. Kecemasan merupakan gejala klinis yang jelas nampak pada pasien dengan penatalaksanaan medis, dalam populasi psikiatri gangguan kecemasan sekitar 5-15\% dari keseluruhan pasien psikiatri, sedangkan dalam populasi umum prevalensinya 2-4,7 \% .

Diperkirakan $80 \%$ dari semua pasien yang akan menjalani operasi mengalami kecemasan, ini didapatkan dari berbagai studi yang dilakukan, hasilnya menunjukkan terdapat peran negatif dari stress, dalam mempengaruhi kesehatan individu. Tugas perawat dalam 
mengelola pasien preoperasi dan post operasi adalah memberikan keperawatan secara komprehensif. Salah satunya adalah pemantauan kondisi psikologis pasien yang selama ini diabaikan, dimana kondisi psikologis pasien yang akan menjalani operasi dipengaruhi oleh beberapa faktor (Ulfa, 2017). Sumber dukungan utama bagi pasien yang akan menjalani operasi adalah dukungan yang diperoleh dari keluarga.

Respon psikologis yang terjadi akibat kecemasan memerlukan dukungan mental dari keluarga guna meningkatkan semangat hidup pasien. Dukungan keluarga penting sebagai startegi preventif dalam menurunkan kecemasan pre operasi. Untuk memahami keinginan pasien, keluarga dapat memberikan ekspresi pengharapan positif, dukungan instrumental, bantuan finansial, dukungan informasional dan dukungan emosional (Matondang, 2017).

Setelah dilakukan survey pendahuluan dan dilakukan wawancara dengan 5 pasien preoperasi di RSUD Dr. Moewardi, ternyata didapatkan keterangan bahwa 3 pasien mengalami gangguan tidur (insomnia) dan 2 pasien merasakan gugup dan gelisah. Semua pasien yang diwawancarai mendapatkan support dan dukungan moril dari keluarganya, tetapi ada 3 pasien yang merasakan tidak ada perbedaannya antara apabila ada anggota keluarga atau tidak adanya anggota keluarga didekatnya. Lainnya menjawab ada perbedaan yang sangat berarti. Pasien tersebut merasa gelisah jika tidak ada anggota keluarga yang mendampinginya. Mereka merasa lebih tenang dan nyaman jika ada anggota keluarga yang memperhatikan, menenangkan hati dan mendoakannya.

Berdasarkan latar belakang tersebut maka peneliti tertarik untuk melakukan penelitian tentang pemberdayaan keluarga dengan tingkat kecemasan pasien rawat inap di RSUD Dr. Moewardi.

\section{TINJAUAN PUSTAKA}

Kecemasan pasien menghadapi preoperasi adalah kecemasan terhadap masalah menjelang pelaksanaan operasi yang akan dihadapi pasien dimana merupakan suatu perasaan yang tidak menyenangkan dan merupakan reaksi normal terhadap situasi yang menimbulkan stress dan konflik, bersifat subyektif, dan timbul karena individu merasa dirinya menghadapi ketegangan. Kecemasan pasien preoperasi termasuk state anxiety yaitu gejala kecemasan yang timbul bila individu dihadapkan pada situasi tertentu situasi-situasi ini akan menyebabkan individu mengalami kecemasan dan gejalanya akan selalu tampak selama situasi tersebut ada (Masluchah \& Sutrisno, 2010).

Salah satu faktor yang menyebabkan tingginya kecemasan pada individu adalah tingkat kedekatan pasien dengan keluarga (Mantgomery, 2010). Faktor yang mempengaruhi kecemasan pasien menurut Kaplan dan Sadock (1997) dalam Lutfa dan Uliya (2008) antara lain adalah faktor intrinsik (usia pasien, pengalaman pasien menjalani pengobatan, konsep diri dan peran) dan faktor ekstrinsik (kondisi medis/ diagnosis penyakit, tingkat pendidikan, akses informasi, proses adaptasi, tingkat sosial ekonomi, jenis tindakan pembedahan, komunikasi terapeutik).

Penelitian yang dilakukan Matondang (2017) tentang dukungan keluarga terhadap kecemasan pasien dari 38 responden didapatkan hasil bahwa 2 pasien mengalami cemas berat dengan support system yang rendah, cemas sedang 25 orang $(65,8 \%)$ dengan dukungan keluarga kategori sedang dan 1 orang mengalami kecemasan tinggi, serta responden dengan dukungan tinggi mengalami kecemasan rendah sebanyak 2 orang.

Caplan (1964) dalam Friedman (2010) menjelaskan bahwa keluarga memiliki beberapa fungsi dukungan yaitu: dukungan informasional, dukungan penilaian, dukungan instrumental dan dukungan emosional. Dukungan sosial sebagai koping keluarga, baik dukungan-dukungan yang bersifat eksternal maupun internal.

Faktor yang mempengaruhi dukungan keluarga menurut Suriani dan Faridah (2009) meliputi: pola asuh anak (anak yang berasal dari keluarga kecil cenderung menerima perhatian dan dukungan dari orang tuanya lebih besar atau banyak dibanding anak yang berasal dari keluarga yang mempunyai banyak anak), usia (orang yang lebih muda cenderung untuk tidak bisa merasakan atau mengenali kebutuhan anakanaknya dan juga lebih egosentris dibandingkan dengan orang tua yang lebih tua) dan sosial ekonomi (sosial ekonomi meliputi tingkat pendapatan atau pekerjaan orang tua dan tingkat pendidikan).

Keluarga dapat memberikan dukungan yang dapat berperan sebagai kekuatan individu dalam melawan penyakit atau saat dihadapkan pada stressor. Baik secara langsung maupun tidak langsung dukungan dari keluarga dapat mengurangi rasa cemas pada seseorang yang dirawat dirumah sakit. Dukungan yang diberikan dapat berupa dukungan informasional, dukungan penilaian, dukungan instrumental dan dukungan emosional. Orang yang merasa 
mendapat dukungan keluarga, secara emosional merasa nyaman karena diperhatikan, mendapat saran atau kesan yang menyenangkan pada dirinya, individu akan merasa disayang, dihargai, menjadi percaya diri, serta mampu melihat dan menumbuhkan harapan masa depan sehingga mampu menangkal dan mengurangi kecemasan (Hartono et al, 2009).

\section{METODE}

Metode penelitian yang digunakan adalah dengan menggunakan metode penelitian analitik dan metode pendekatan yang digunakan dalam penelitian ini adalah metode cross sectional. Lokasi penelitian ini di Ruang Inap Mawar II dan Mawar III RSUD Dr. Moewardi. Populasi dalam penelitian ini adalah pasien preoperasi ORIF yang dirawat di Ruang Inap Mawar II dan Mawar III RSUD Dr. Moewardi. Teknik pengambilan sampel dengan menggunakan purposive sampling dengan jumlah sampel sebanyak 57 responden. Pengumpulan data pada penelitian ini menggunakan data primer dan data sekunder. Data primer diperoleh peneliti pasien preoperasi ORIF dengan menggunakan kuesioner serta data sekunder diperoleh peneliti berasal dari Rekam Medis RSUD Dr. Moewardi.

Analisa data dilakukan dengan analisa univariate dan bivariate. Instrumen yang digunakan untuk mengumpulkan data adalah kuesioner yang berisi serangkaian pertanyaan yang mengacu pada variabel bebas dan variabel terikat yang digunakan.

\section{HASIL dan PEMBAHASAN}

Berdasarkan hasil penelitian didapat hasil bahwa karakteristik umur responden sebagian besar berusia 26 - 30 tahun, berjenis kelamin perempuan, dengan jenjang Pendidikan terakhir SMA, pekerjaan Swasta serta memiliki riwayat operasi sebelumnya.

\section{Karakteristik Responden}

Karakteristik responden yang digunakan meliputi; umur, jenis kelamin, pekerjaan, pendidikan, dan riwayat operasi.

\section{Umur responden}

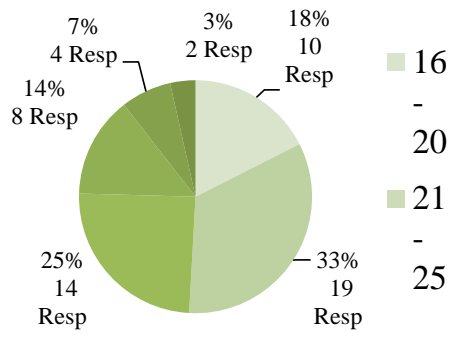

Gambar 1 Diagram Distribusi Frekuensi

Responden Berdasarkan Umur $(n=57)$
Berdasarkan hasil penelitian mengenai umur responden, menunjukkan bahwa umur responden terbanyak adalah 26-30 tahun sebanyak 19 responden (33\%) dan paling sedikit adalah 51-55 tahun sebanyak 2 orang (3\%).

\section{Jenis kelamin responden}

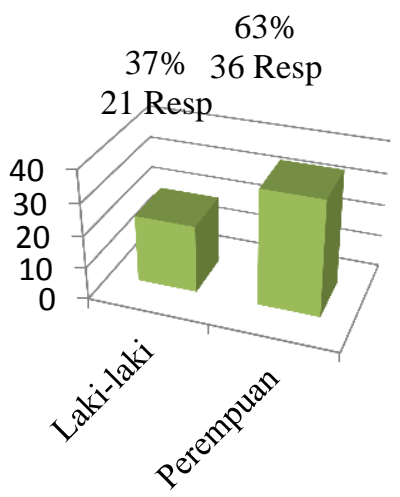

Gambar 2 Diagram Distribusi Frekuensi

Responden Berdasarkan Jenis Kelamin $(n=57)$

Berdasarkan hasil penelitian mengenai jenis kelamin responden, menunjukkan bahwa jenis kelamin responden terbanyak yaitu perempuan sebanyak 36 responden $(63 \%)$.

\section{Pendidikan terakhir responden}

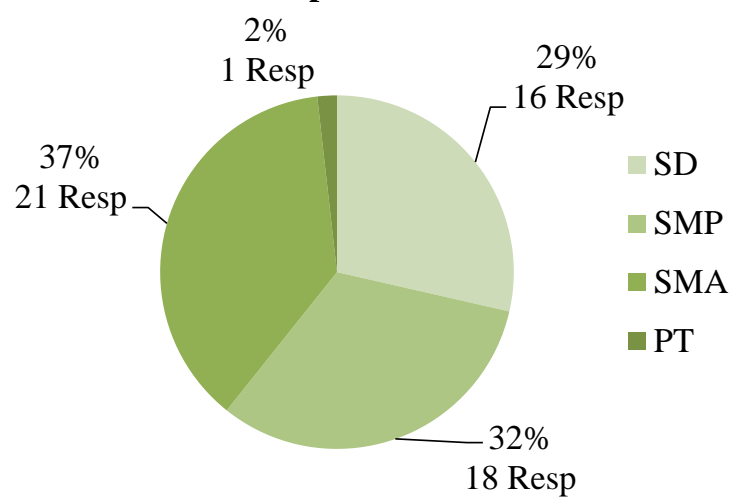

Gambar 3 Diagram Distribusi Frekuensi Responden Berdasarkan Pendidikan Terakhir (n $=57$ )

Berdasarkan hasil penelitian mengenai pendidikan terakhir responden, menunjukkan bahwa tingkat pendidikan responden terbanyak adalah SMA sebanyak 21 responden (37\%) dan paling sedikit adalah Perguruan Tinggi sebanyak 1 orang (2\%). 


\section{Pekerjaan responden}

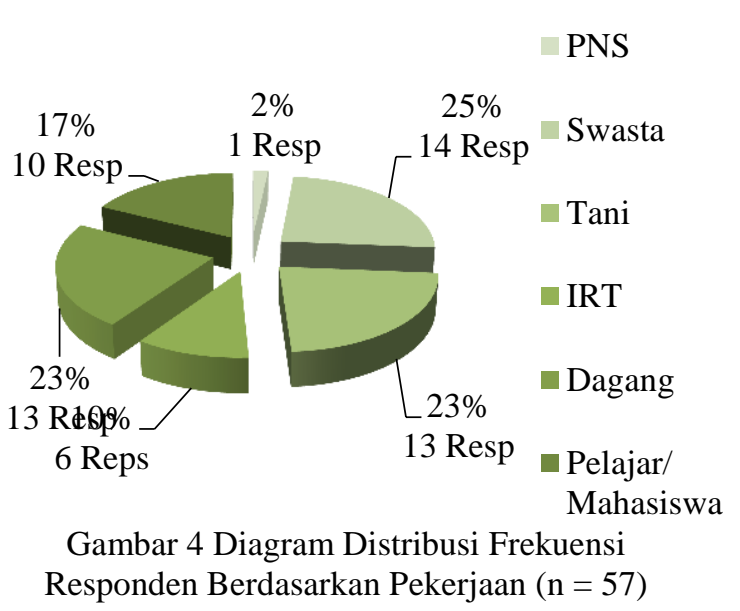

Berdasarkan hasil penelitian mengenai pekerjaan responden, menunjukkan bahwa pekerjaan responden terbanyak adalah swasta sebanyak 14 responden (25\%) dan paling sedikit adalah PNS sebanyak 1 orang $(2 \%)$.

\section{Riwayat operasi responden}

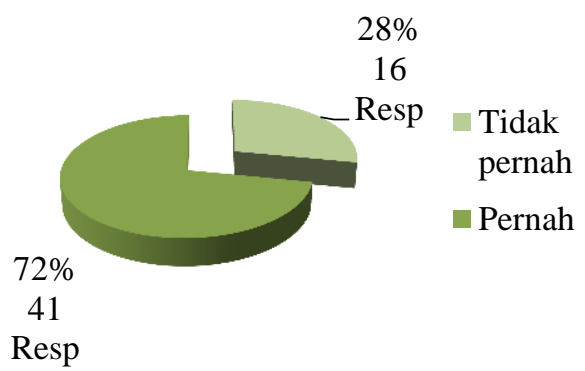

Gambar 5 Distribusi Frekuensi Responden

Berdasarkan Riwayat Operasi ( $\mathrm{n}=57$

Berdasarkan hasil penelitian mengenai riwayat operasi responden, menunjukkan bahwa riwayat operasi yang terbanyak adalah pernah operasi sebanyak 41 responden (72\%).

\section{Dukungan keluarga}

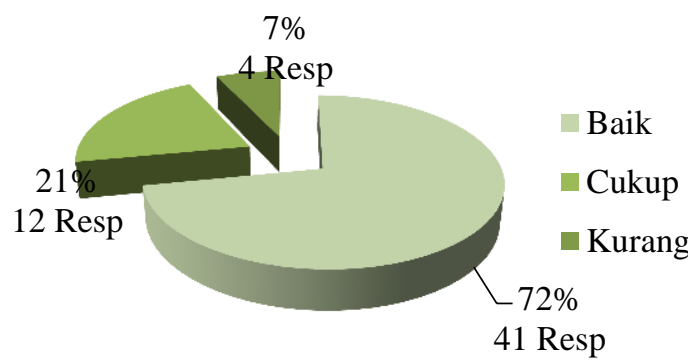

Gambar 6 Diagram Distribusi Frekuensi Responden Berdasarkan Dukungan Keluarga (n $=57$ )

Berdasarkan hasil penelitian mengenai dukungan keluarga responden, menunjukkan bahwa paling banyak responden mempunyai dukungan keluarga baik sebanyak 41 responden $(72 \%)$

\section{Tingkat kecemasan}

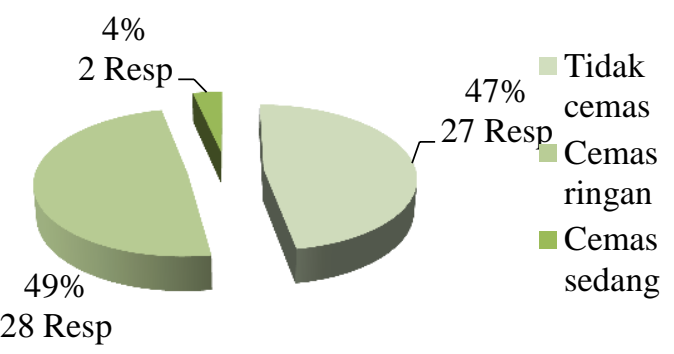

Gambar 7 Diagram Distribusi Frekuensi Responden Berdasarkan Tingkat Kecemasan (n $=57$ )

Berdasarkan hasil penelitian mengenai tingkat kecemasan responden, menunjukkan bahwa tingkat kecemasan responden terbanyak adalah kecemasan ringan sebanyak 28 responden (49\%). Responden yang mengalami kecemasan berat dan berat sekali/panik tidak ada $(0 \%)$.

Tabel 1 Hubungan Pemberdayaan Keluarga dalam menurunkan kecemasan Pasien $(\mathrm{n}=57)$

\begin{tabular}{|c|c|c|c|c|c|c|c|c|c|}
\hline \multirow{3}{*}{\multicolumn{2}{|c|}{ Variabel }} & \multicolumn{6}{|c|}{ Tingkat Kecemasan } & \multicolumn{2}{|c|}{ Total } \\
\hline & & \multicolumn{2}{|c|}{ Tidak cemas } & \multicolumn{2}{|c|}{ Ringan } & \multicolumn{2}{|c|}{ Sedang } & \multirow[b]{2}{*}{$\mathrm{N}$} & \multirow[b]{2}{*}{$\%$} \\
\hline & & $\mathrm{N}$ & $\%$ & $\mathrm{~N}$ & $\%$ & $\mathrm{~N}$ & $\%$ & & \\
\hline \multirow{3}{*}{$\begin{array}{l}\text { Dukungan } \\
\text { Keluarga }\end{array}$} & Baik & 21 & $36.8 \%$ & 20 & $35.1 \%$ & 0 & $0 \%$ & 41 & $71.9 \%$ \\
\hline & Cukup & 6 & $10.5 \%$ & 6 & $10.5 \%$ & 0 & $0 \%$ & 12 & $21.1 \%$ \\
\hline & Kurang & 0 & $0 \%$ & 2 & $3.5 \%$ & 2 & $3.5 \%$ & 4 & $7.0 \%$ \\
\hline Total & & 27 & $47.4 \%$ & 28 & $49.1 \%$ & 2 & $3.5 \%$ & 57 & $100 \%$ \\
\hline
\end{tabular}

Sumber: Data Primer 
Berdasarkan tabel 1 menunjukkan bahwa dari 57 responden, dukungan keluarga yang paling banyak dimiliki responden adalah dukungan keluarga dengan kategori baik yaitu sebanyak 41 responden. Responden yang memiliki dukungan keluarga baik tidak mengalami kecemasan sebanyak 21 responden $(36,8 \%)$. Responden yang memiliki dukungan keluarga cukup tidak mengalami kecemasan dan kecemasan ringan masing-masing sebanyak 6 responden $(10,5 \%)$, dan responden dengan dukungan keluarga kurang mengalami cemas ringan dan cemas sedang masing-masing sebanyak 2 respoden.

Hasil analisa statistic dengan menggunakan Kendall Tau dengan taraf kesalahan $(\alpha)$ 5\% didapatkan hasil nilai $\mathrm{r}=$ 0,349 . Hasil perhitungan dengan rumus $\mathrm{Z}$, didapatkan harga $z_{\text {hitung }}$ lebih besar dari $z_{\text {tabel }}$ $(3,83>1,96)$ dengan $\rho$-value $0,000<0,05$ sehingga Ho ditolak dan Ha diterima, hal ini berarti bahwa terdapat hubungan pemberdayaan keluarga dengan tingkat kecemasan pada pasien.

\section{PEMBAHASAN}

Umur

Berdasar data karakteristik responden pasien dapat dilihat bahwa dari 57 responden, umur responden yang terbanyak adalah umur 26-30 tahun yaitu sebanyak 19 responden (33\%). Penelitian yang relatif sama dari Nursholikhatin et al (2018) menunjukkan bahwa faktor usia memberikan kontribusi terhadap terjadinya kecemasan bagi seseorang.

Setiap rentang usia (bayi-lansia) memiliki pemahaman dan respon terhadap perubahan kesehatan yang berbeda-beda, menurut Amelia (2014) usia mempengaruhi terhadap daya tangkap dan pola piker seseorang. Semakin bertambah usia semakin berkembang pula daya tangkap dan pola pikirnya, sehingga pengetahuan yang diperolehnya semakin membaik.

Penjelasan tersebut diperkuat oleh pernyataan Kaplan dan Sadock (1997) dalam penelitian Lutfa dan Maliya (2008) bahwa gangguan kecemasan dapat terjadi pada semua usia, lebih sering pada usia dewasa dan lebih banyak pada wanita. Sebagian besar kecemasan terjadi pada umur 21-45 tahun.

Hasil penelitian ini berbanding terbalik dengan penelitian yang dilakukan Jafar (2009) seseorang remaja atau masih muda lebih cenderung mengalami cemas dibandingkan dengan tingkat umur yang semakin dewasa dan lebih tua. Semakin meningkatnya umur seseorang maka frekuensi kecemasan seseorang makin berkurang saat menjalani operasi.

\section{Jenis Kelamin}

Berdasar data karakteristik responden pasien preoperasi ORIF dapat dilihat bahwa dari 57 responden, jenis kelamin yang terbanyak adalah perempuan yaitu sebanyak 36 responden (63\%) dan yang paling sedikit adalah laki-laki yaitu sebanyak 21 responden (37\%).

Qulsum et al (2012) mengatakan bahwa perempuan lebih cenderung emosional, mudah meluapkan perasaannya, sementara lakilaki bersifat objektif dan dapat berpikir rasional sehingga mampu berpikir dan dapat mengendalikan emosi. Hal yang sama dikemukakan oleh Halgin dan Withbourne (2010), kecemasan lebih sering dialami perempuan daripada laki-laki karena perempuan sering menggunakan perasaan untuk menyikapi dan menghadapi sesuatu dalam hidupnya sedang laki-laki selalu menggunakan pikiran dalam menghadapi situasi yang mengancam dirinya.

\section{Pendidikan}

Berdasardata karakteristik responden tentang pendidikan menunjukkan bahwa dari 57 responden, pendidikan terakhir yang terbanyak adalah SMA yaitu sebanyak 21 responden (37\%) dan yang paling sedikit adalah PT yaitu sebanyak 1 responden (2\%).

Status Pendidikan yang rendah rentan sekali mengalami kecemasan dibandingkan dengan Pendidikan tinggi. Semakin tinggi tingkat Pendidikan seseorang maka dapat berpikir secara rasional dan dapat mengatasi emosi dengan baik sehingga kecemasan yang dialami seseorang akan berkurang (Pawatte et $a l, 2013)$. Pendidikan pada umumnya berguna dalam merubah pola pikir, pola bertingkah laku dan pola pengambilan keputusan. Tingkat pendidikan yang cukup akan lebih mudah dalam mengidentifikasi stresor dalam diri sendiri maupun dari luar dirinya. Tingkat pendidikan juga mempengaruhi kesadaran dan pemahaman terhadap stimulus.

\section{Pekerjaan}

Berdasar hasil penelitian menunjukkan bahwa dari 57 responden, pekerjaan yang terbanyak adalah swasta yaitu sebanyak 14 responden $(25 \%)$ dan yang paling sedikit adalah PNS yaitu sebanyak 1 responden (2\%).

Secara umum responden yang tidak cemas sampai panik dalam menghadapi operasi berhubungan dengan pekerjaan terdistribusi merata. Pekerjaan responden tidak berpengaruh atau hanya punya pengaruh yang kecil terhadap tingkat kecemasan, hal ini bisa dilihat dari responden yang bekerja sebagai petani tidak 
menjamin tingkat kecemasannya akan berat, sebaliknya responden yang bekerja sebagai PNS juga tidak menjamin akan mengalami kecemasan ringan.

Menurut Friedman (2010) faktor sosial dan psikososial dapat meningkatkan resiko terjadinya penyakit dan mempengaruhi cara seseorang mendefinisikan dan bereaksi terhadap penyakitnya. Semakin tinggi tingkat ekonomi seseorang biasanya akan lebih cepat tanggap terhadap gejala penyakit yang dirasakan. Sehingga ia akan segera mencari pertolongan ketika dia merasa ada gangguan pada kesehatannya.

\section{Riwayat Operasi}

Berdasardata karakteristik responden dapat dilihat bahwa dari 57 responden, riwayat operasi yang terbanyak adalah pernah operasi yaitu sebanyak 41 responden $(72 \%)$ dan yang paling sedikit adalah tidak pernah operasi yaitu sebanyak 16 responden (28\%).

Kaplan dan Sadock dalam penelitian Lutfa dan Maliya (2008) menyatakan bahwa kemampuan individu dalam merespon penyebab kecemasan ditentukan oleh beberapa faktor, salah satunya adalah adanya pengalaman terhadap stressor. Pengalaman awal pasien dalam pengobatan merupakan pengalamanpengalaman yang sangat berharga yang terjadi pada individu terutama untuk masa-masa yang akan datang. Pengalaman awal ini sebagai bagian penting dan bahkan sangat menentukan bagi kondisi mental individu di kemudian hari. Pengalaman individu tentang pembedahan kurang, maka cenderung mempengaruhi peningkatan kecemasan saat menghadapi tindakan pembedahan.

\section{Dukungan Keluarga}

Berdasarhasil penelitian menunjukkan bahwa dari 57 responden, sebagian besar responden mendapat dukungan keluarga kategori baik yaitu sebanyak 41 orang $(47,4 \%)$, dan hanya 4 orang $(7,0 \%)$ mendapat dukungan kurang, ini menunjukkan bahwa kebanyakan pasien preoperasi di Ruang Inap RSUD Dr. Moewardi selama dilakukan penelitian mendapatkan dukungan yang baik dari keluarga.

Friedman (2010) menyatakan bahwa dukungan keluarga merupakan sikap, tindakan dan penerimaan keluarga terhadap penderita yang sakit. Dukungan keluarga dapat bersumber dari internal maupun eksternal. Dukungan keluarga internal antara lain dukungan dari suami atau istri, dari saudara kandung, atau dukungan dari anak. Dukungan keluarga eksternal berasal dari sahabat, lingkungan pekerjaan, tetangga, sekolah, keluarga besar, kelompok sosial, kelompok rekreasi, tempat ibadah, praktisi kesehatan.

Menurut Matodang (2017), apabila pasien mendapat penilaian negative maka akan berdampak buruk bagi keberlangsungan pengobatannya. Bantuan finansial merupakan bantuan nyata yang efektif mengurangi kecemasan, dalam hal ini dapat berupa biaya pengobatan. Dukungan terutama dari orang tua dan pasangan sangat membantu dalam membawa pikiran positif dan menghindarkan penderita dari perasaan menolak pada keadaan yang sedang dialami. Muncul perasaan menerima menimbulkan suatu harapan dan semangat baru pada penderita sehingga semangat melakukan sesuatu seperti latihan berjalan akan tumbuh.

\section{Tingkat Kecemasan Preoperasi}

Berdasar data tingkat kecemasan pasien preoperasi dapat dilihat bahwa dari 54 responden, sebanyak 27 responden $(47,4 \%)$ tidak mengalami kecemasan, 2 responden $(3,5 \%)$ mengalami cemas sedang, dan paling banyak responden mengalami kecemasan ringan sebanyak 28 responden $(49,1 \%)$, sedangkan responden yang mengalami cemas berat dan cemas berat sekali/ panik tidak ada. Hasil tersebut sesuai dengan penelitian Ulfa (2017) yang menyatakan bahwa $80 \%$ pasien mengalami kecemasan dalam menghadapi operasi.

Hal sama juga dikemukakan oleh Nursholikhatin et al (2018) dalam penelitiannya menyatakan bahwa menjelang operasi pasti semua orang akan mengalami kecemasan. Kecemasan muncul seiring dengan pandangan dan pemahaman seseorang terhadap operasi itu sendiri. Kebanyakan seseorang akan merasa takut menjelang operasi. Perasaan takut muncul seiring dengan adanya suatu ancaman seperti: kecacatan, nyeri, atau rasa sakit saat operasi, kegagalan operasi, kematian dll. Pandangan dan pemahaman seseorang dipengaruhi oleh usia, Pendidikan dan pekerjaan (status social) seseorang.

\section{Hubungan Dukungan Keluarga Dengan Tingkat Kecemasan Preoperasi}

Hasil korelasi antara dukungan keluarga dengan tingkat kecemasan pada pasien preoperasi ORIF dengan menggunakan uji korelasi Kendal Tau didapatkan hasil $\mathrm{r}=-0,349$ dengan nilai signifikansi sebesar 0,05. Hasil tersebut mempunyai arti bahwa terdapat korelasi antara dukungan keluarga dengan tingkat kecemasan pada pasien preoperasi ORIF. 
Berdasarkan hasil penelitian menujukkan bahwa dari 57 responden $(100 \%)$ hanya $2(3,5 \%)$ yang mengalami kecemasan sedang jadi sebagian besar responden tidak mengalami kecemasan dalam menghadapi operasi ORIF. Hasil penelitian tersebut sesuai dengan penelitian yang dilakukan oleh Ulfa (2017) dalam penelitiannya menyatakan bahwa peningkatan dukungan keluarga diikuti oleh penurunan tingkat kecemasan, hal ini menunjukkan semakin baik dukungan keluarga semakin berkurang tingkat kecemasan pasien preoperasi terencana. Dukungan keluarga yang adekuat diharapkan menurunkan kecemasan pasien, sehingga pasien bisa fokus pada pengobatan dan kesembuhannya.

Hasil yang sama juga dikemukakan oleh Matondang (2017) dalam penelitiannya, semakin tinggi dukungan keluarga yang diberikan semakin rendah tingkat kecemasan yang dialami oleh pasien. Pasien yang mengalami kecemasan berat, hal ini dikarenakan keluarga jarang menjenguk atau menunggu ketika pasien di rumah sakit, sehingga akan berdampak pada kecemasan yang berat dikarenakan pasien merasa tidak diperhatikan. Selain itu dapat juga disebabkan karena keluarga kurang menyediakan waktu dan fasilitas baik keperluan yang diperlukan pasien ketika dirawat maupun fasilitas uang untuk keperluan biaya perawatan pasien. Keluarga yang tidak pernah memberikan informasi terkait dengan penyakit dan hal-hal yang bisa memperburuk penyakit pasien dan keluarga yang kurang memberikan support agar pasien cepat sembuh.

Pembedahan sering menyebabkan kelemahan yang bersifat sementara atau permanen sehingga membutuhkan bantuan tambahan selama masa pemulihan. Biasanya klien tidak langsung dapat melakukan aktifitas fisik yang kadarnya sama seperti saat sebelum klien sakit. Keluarga merupakan sumber terpenting bagi klien yang mengalami keterbatasan fisik dan keluarga memberi dukungan emosional yang dibutuhkan untuk memotivasi klien mencapai kembali status kesehatan sebelumnya (Potter \& Perry, 2011). Menurut Parjanto (2009) dalam Nursholikhatin et al., (2018) salah salah satu faktor yang mempengaruhi tingkat kecemasan adalah adanya support system keluarga atau dukungan keluarga yang merupakan bagian dari dukungan social yang mempunyai pengaruh terhadap kesehatan. Jika kita merasa didukung oleh lingkungan maka segala sesuatu dapat menjadi lebih mudah pada waktu menjalani kejadian-kejadian yang menegangkan. Hartono et al, (2009), dukungan yang diberikan dapat berupa dukungan informasional, dukungan penilaian, dukungan instrumental dan dukungan emosional. Orang yang merasa mendapat dukungan keluarga, secara emosional merasa nyaman karena diperhatikan, mendapat saran atau kesan yang menyenangkan pada dirinya, individu akan merasa disayang, dihargai, menjadi percaya diri, serta mampu melihat dan menumbuhkan harapan masa depan sehingga mampu menangkal dan mengurangi kecemasan. Jhonson dan Leny (2010) menyatakan bahwa keluarga berperan dalam menentukan cara asuhan yang diperlukan anggota keluarga yang sakit. Keberhasilan keperawatan di rumah sakit dapat menjadi sia-sia jika tidak dilanjutkan oleh keluarga. Secara empiris dapat dikatakan bahwa kesehatan anggota keluarga dan kualitas kehidupan keluarga menjadi sangat berhubungan atau signifikan. Semakin pasien mendapatkan dukungan keluarga pasien akan merasa aman, nyaman dan terlindungi. Pasien dapat mengekspresikan ketakutan dan kecemasannya pada keluarga sehingga mengurangi kecemasan dan ketakutan yang berlebihan.

\section{KESIMPULAN}

Pemberdayaan keluarga pasien di Ruang Inap RSUD Dr. Moewardi adalah pada kategori baik sedangkan pada tingkat kecemasan pasien preoperasi yang terbanyak adalah tingkat kecemasan kategori cemas ringan. Terdapat hubungan antara pemberdayaan keluarga dengan tingkat kecemasan pada pasien Ruang Inap RSUD Dr. Moewardi.

\section{DAFTAR PUSTAKA}

Asmadi. 2008. Kebutuhan Dasar Manusia. Jakarta: Salemba Medika.

Friedman, M. 2010. Keperawatan Keluarga Teori dan Praktik (Family Nursing: Theory and Practice). Jakarta: EGC.

Halgin, R. P., \& Withbourne, S. K. 2010. Abnormal Psychology Clinical Perspectives on psycholgycal disorder. Jakarta: Salemba Humanika.

Hartono, Marsito, Asti. 2009. Hubungan Dukungan Sosial Keluarga Dengan Tingkat Kecemasan Paien Rawat Inap di RSU PKU Muhammadiyah Gombong. Jurnal Ilmiah Kessehatan Keperawatan. Vol 5. No 1. Februari 2009: 34-42.

Jhonson \& Leny. 2010. Keperawatan Keluarga. Pluss Contoh Askep Kleuarga. Yogyakarta: Nuha Medika. 
Mantgomery, Guy H., et al. 2010. Presurgery Psychological Factors Predict Pain, Nausea, and Fatigue One Week After Breast Cancer Suergery. Jurnal of Pain and Symtom Management Vol. 39 No. 6, 6 June 2010.

Matondang, Zulhajji. 2017. Hubungan Dukuangan Keluarga Dengan Tingkat Kecemasan Pada Pasien Pre Anestesi Dengan Tindakan Spinal Anestesi di RSU Dr. Pirngadi. Jurnal Keperawatan Flora. Volume X. No 2. Juli 2017: 1-6.

Nursholikhatin, et al., 2018. Hubungan Dukungan Keluarga dengan Tingkat Kecemasan Pasien Pre Operasi Katarak di Klinik Mata Royal EDC Mojosari. Stikes Bina Sehat PPNI Mojokerto. [Skripsi]
Potter \& Patricia A. 2011. Buku Ajar Fundamental Keperawatan: Konsep, Proses dan Praktik vol. 2. Jakarta: EGC.

Qulsum A, Ismonah, Meikawati W. 2012. Perbedaan Tingkat Kecemasan Pada Pasien Pre Operasi Sebelum dan Sesudah Pemberian Terapi Musik Klasik di RSUD Tugurejo Semarang. Jurnal Ilmu Keperawatan dan Kebidanan. 2012; 1(1).

Suriani \& Faridah. 2009. Hubungan Antara Dukungan Keluarga Dengan Tingkat Kecemasan Hospitalisasi Anak Usia Sekolah di Ruang Perawatan Anak Paviliun DII dan Paviliun V Rumah Sakit TNI-AL Dr. Ramelan Koa Surabaya. Jurnal Infokes STIKES Insan Unggul Surabaya. 2009: 11-20. 